\title{
Impact of an excise tax on the consumption of sugar-sweetened beverages in young people living in poorer neighbourhoods of Catalonia, Spain: a difference in differences study
}

\author{
Miguel Ángel Royo-Bordonada ${ }^{1 *}$ (D), Carlos Fernández-Escobar ${ }^{1}$, Lorena Simón², Belen Sanz-Barbero ${ }^{1,3}$ and
} Javier Padilla ${ }^{4}$

\begin{abstract}
Background: Sugar-sweetened beverage consumption is contributing to the obesity epidemic. On 28 March 2017, Catalonia enacted a law levying an excise tax on sugar-sweetened beverages for public health reasons. The purpose of this study is to assess the impact of the tax on the consumption of sugar-sweetened beverages in Catalonia (Spain).

Methods: Before-and-after study to assess changes in the prevalence of consumption of sugar-sweetened beverages among 1929 persons aged 12 to 40 years residing in low-income neighbourhoods of Barcelona (intervention) and Madrid (control). Beverage consumption frequency was ascertained via a validated questionnaire administered during the month prior to the tax's introduction (May 2017) and again at 1 year after it had come into force. The effect of the tax was obtained using Poisson regression models with robust variance weighted using propensity scores.

Results: While the prevalence of regular consumers of taxed beverages fell by $39 \%$ in Barcelona as compared to Madrid, the prevalence of consumers of untaxed beverages remained stable. The main reason cited by more than two-thirds of those surveyed for reducing their consumption of sugar-sweetened beverages was the increase in price, followed by a heightened awareness of their health effects.
\end{abstract}

Conclusions: The introduction of the Catalonian excise tax on sugar-sweetened beverages was followed by a reduction in the prevalence of regular consumers of taxed beverages.

Keywords: Taxes, Sugar-sweetened beverages, Spain, Catalonia

\section{Background}

The prevalence of obesity among the Spanish population has risen progressively in recent decades [1], reaching figures of over $20 \%$ in adults [2] and around $10 \%$ in children [3]. High body mass index is the leading cause of disease burden in Spain, being responsible for more than $10 \%$ of disability-adjusted life years, essentially due to its

\footnotetext{
* Correspondence: mroyo@isciii.es

${ }^{1}$ National School of Public Health, Institute of Health Carlos III, Sinesio

Delgado, 8, 28029 Madrid, Spain

Full list of author information is available at the end of the article
}

association with cardiovascular diseases, several types of cancer, and metabolic and endocrine diseases [4]. In Spain, prevalence of obesity displays an inverse socioeconomic gradient, both at a macro level, with per capita income in the Autonomous Regions, and at a micro level, with families' educational level and socio-economic status $[2,5]$.

Globally-speaking, consumption of sugar-sweetened beverages (SSBs) ranks high among the many causes of obesity [6], and this is equally true of the Spanish population, where an increment in soft drinks consumption

(c) The Author(s). 2019 Open Access This article is distributed under the terms of the Creative Commons Attribution 4.0 International License (http://creativecommons.org/licenses/by/4.0/), which permits unrestricted use, distribution, and reproduction in any medium, provided you give appropriate credit to the original author(s) and the source, provide a link to the Creative Commons license, and indicate if changes were made. The Creative Commons Public Domain Dedication waiver (http://creativecommons.org/publicdomain/zero/1.0/) applies to the data made available in this article, unless otherwise stated. 
of $100 \mathrm{ml}$ was associated with a $0.21 \mathrm{~kg} / \mathrm{m}^{2}$ increase in BMI [7]. As SSBs contain energy in liquid form which generates low satiety levels and a compensatory response inadequate to counteract excess calories, they may alter the balance between energy intake and expenditure [8]. Furthermore, intake of SSBs triggers high blood sugar peaks, which favour insulin resistance and diabetes [9], and is associated with the development of hypertension and hyperlipidaemia [10]. Consumption of one SSB per day is estimated to increase cardiovascular risk, both fatal and non-fatal, by $20 \%$ [11].

According to the 2014 European Health Survey, 35.9\% of the Spanish population aged 15 years and over were regular consumers of soft drinks [12]. It has been estimated that $0.6 \%$ of all deaths in Spain are attributable to such consumption, with a total of 30 annual deaths per million adults [13]. Consumption is higher among adolescents, with a mean intake of soft drinks, fruit juices and drinks of over $450 \mathrm{~mL} /$ day [14], which accounts for more than $6 \%$ of total calorie intake [15]. As with obesity, here in Spain SSB consumption displays an inverse gradient with socio-economic level. According to data drawn from the 2012 National Health Survey, the daily percentage of SSB consumers in the lower socioeconomic stratum of the Spanish population is two to three times higher than that in the high-income bracket, among adults and children alike $[3,16]$.

At the World Health Organisation (WHO) European Ministerial Conference on Nutrition and Noncommunicable Diseases held in Vienna in 2013, the Ministers of Health of the European Region Member States undertook to lend impetus to the application of economic tools to promote healthy dietary habits [17]. The European Food and Nutrition Action Plan advocates that consideration be given to food-supply-chain incentives in the form of subsidies and taxation [18], and the WHO Committee Report on eliminating childhood obesity recommends levying a tax on SSBs [19]. In the wake of the initiative launched by the city of Berkeley (California) and countries such as Finland, France, UK, South Africa and Mexico, other cities across the USA and countries around the world started introducing excise taxes on SSBs in 2017 and 2018 [20]. Following this trend [21], on 28 March 2017 Catalonia enacted a law levying an excise tax on SSBs for public health reasons [22]. While fruit drinks, sports drinks, tea and coffee, energy and vegetable drinks, sugar-sweetened milk drinks, shakes, soft drinks, and flavoured water are all subject to this tax, natural fruit juices, fermented milk drinks and drinking yoghurts are exempt. The tax in Catalonia is unique as it was designed through legislation to be fully passed through to prices and includes two 'tiers'. Although a similar UK soft drinks tiered levy was introduced in april 2018, it was designed to be passed through to manufacturers [23]. The law renders the tax payable by the consumer at a rate of 8 centimes per litre for beverages with a sugar content of 5 to $8 \mathrm{~g}$ per 100 $\mathrm{mL}$ and 12 centimes per litre for beverages with higher sugar content, which is expected to raise the price between 10 and $20 \%$ on average, depending on sugar content and container size, rates similar to those applied in other countries with similar statutory measures [24].

Evidence of the effectiveness of excise taxes on SSBs is growing fast, with observed reductions on frequency of consumption in Philadelphia [25] and low-income areas of Berkley [26], and decreased sales in Mexico [27], Barbados [28] and Chile [29]. A recent systematic review of real-word studies concluded that SSB taxes are effective in reducing SSB purchases an dietary intake, suggesting a greater effet for volumetric taxes with sugar thresholds [30]. Besides price mechanisms via which a tax influences consumption, a singalling effect has been described in adults who were aware of the SSB tax [31]. This study evaluated the impact of the tax on the consumption of SSBs in Catalonia, using two samples of Barcelona townspeople (pre- and post-taxation) and, by way of a control group, two comparable samples of Madrid townspeople of similar characteristics, providing the first evidence on consumption for a tiered SSB tax designed to be fully passed through to prices. Moreover, we examined subjects' degree of knowledge of the tax, self-perceived changes in consumption patterns, and the reasons cited by them to account for these changes in the Barcelona post-tax sample.

\section{Methods \\ Design}

We conducted a before-and-after, quasi-experimental study, with a control group for comparison purposes, using repeated application of a non-alcoholic beverage consumption survey to assess the effect of the tax on SSBs in Catalonia. The pre-taxation survey was conducted in April 2017, the month before the tax came into force (1 May 2017), and the post-taxation survey was conducted 1 year later, to avoid confounding due to seasonal variations.

\section{Study subjects and selection of the sample}

The study covered young persons (age range 12-40 years) of both sexes residing in districts with the lower index of disposable family income in Barcelona (Nou Barris and Sant Andreu) [32] and Madrid (Usera and Puente de Vallecas) [33], a population group with a higher SSB consumption on which the tax's foreseeable impact would be greater [34]. A requirement for inviting adolescents aged 12 to 15 years to participate in the study was that they be accompanied by an adult relative. 
In each city, a number of sampling points were selected in busy areas of the study districts, such as markets, bus, rail and underground stations, and the environs of shopping malls or football grounds. Interviewers positioned at the sampling points invited all passers-by to take part in a non-alcoholic beverage consumption survey, asking for their oral consent (and, in the case of adolescents aged 12 to 15 years, the consent of an accompanying family member). The following were excluded from study: any person outside the age range or not residing in the study district; and any person who presented with a disease or intellectual-type disability that prevented him/her from properly supplying the information required. The main goal of the study was only revealed to the participants once they had answered the questionnaire, in order to avoid any risk of bias potentially associated with knowledge of said goal when reporting their consumption patterns.

A total of 3979 persons were invited to participate; of these 1465 (36.8\%) rejected the invitation (Fig. 1). The participation rate was somewhat lower in the pretaxation survey $(61.7 \%)$ than in the post-taxation survey (64.9\%), with a variable distribution by city. Of the 2514 persons who agreed to participate, 459 (18.3\%) were excluded for not residing in the study districts or falling outside the age range, with this percentage being higher in Madrid than in Barcelona both pre- and post-tax. Of the 2055 persons eligible, 95 (4.6\%) were excluded for failing to give reliable answers, due to inadequate comprehension of the questions or to giving incomplete responses, with missing values in questions pertaining to age, consumption of beverages, or most of the covariates. The highest percentage of exclusions was observed in the Barcelona pre-taxation survey, with a figure of 10\%. The final study sample totalled 1929 persons, 986 in the pre-taxation and 943 in the post-taxation surveys.

\section{Data-collection and study variables}

SSB consumption data were gathered by purpose-trained interviewers who administered a survey, which included a section with socio-demographic variables (age, sex, nationality, educational level and occupational status), and a non-alcoholic beverage consumption questionnaire, previously validated and adapted for the Spanish population [35]. The structure of the questionnaire was adapted to ask subjects about their regular consumption (at least once per week) of each type of beverage from the statutory categories, namely, taxed beverages (soft drinks, fruit drinks and energy drinks) and untaxed beverages (sugar-free soft drinks, fruit juices and drinking

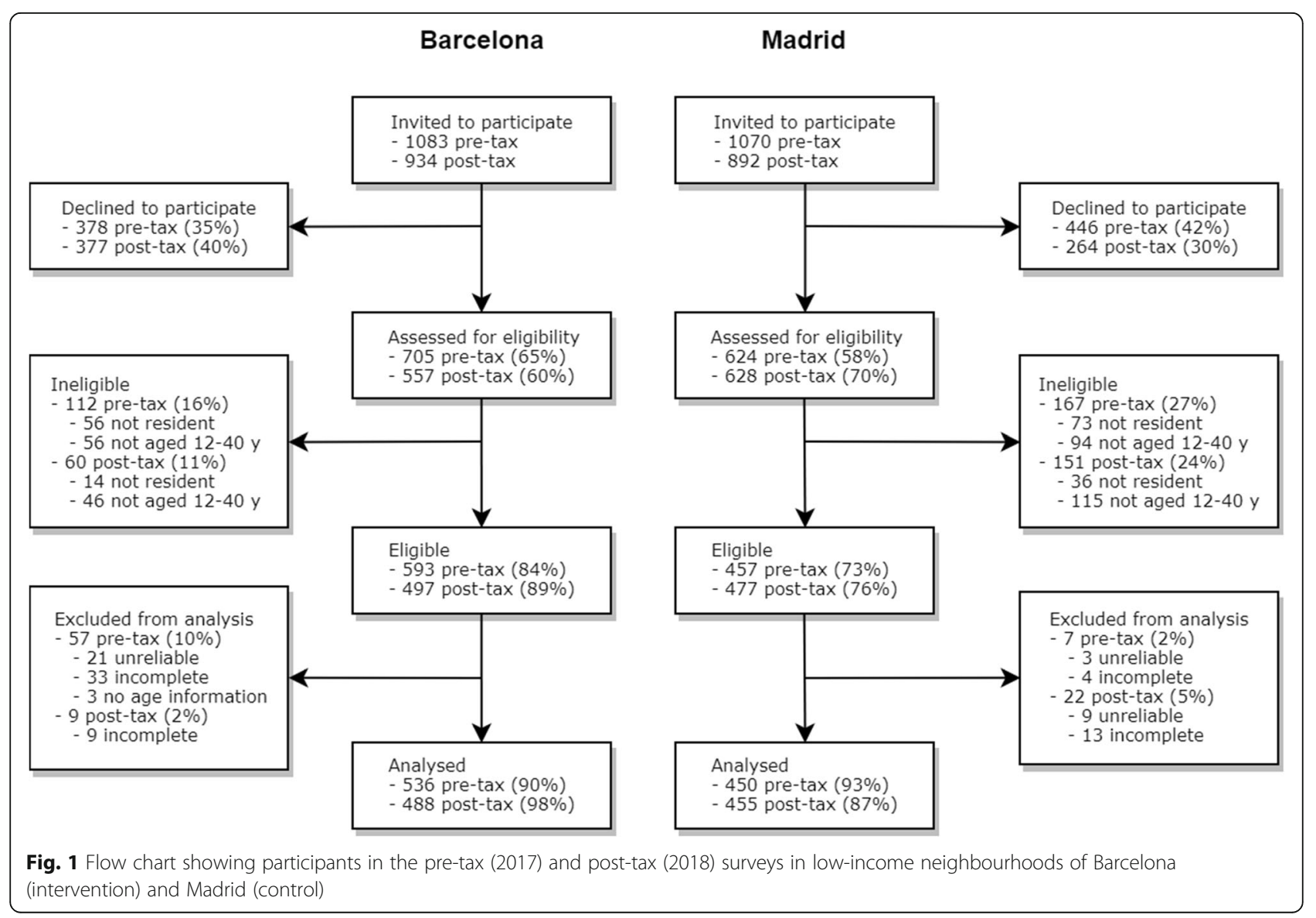


yoghurts). Flavoured water and vegetable drinks were also included in the latter category because the added sugar content of the products available on the market in no case exceeded $5 \mathrm{~g} / 100 \mathrm{~mL}$, the taxation threshold. Sports drinks and sugar-sweetened milk drinks are shown in a separate category, due to the fact that they include some varieties not subject to the tax by reason of their lower sugar content. For each type of beverage included in the questionnaire, subjects were asked whether it was consumed daily or weekly and, if so, whether or not the regularly consumed beverage was an own-brand product.

In the Barcelona post-taxation survey, an additional section was included at the end of the questionnaire, in which subjects were asked if they knew of the tax's existence and if they had changed their SSB consumption patterns after the tax's entry into force, whether by reducing the amount consumed or totally or partially replacing it with an untaxed or own-brand beverage. Lastly, those who reported that they had changed their consumption habits were asked whether the reasons for the change were connected with the increase in the price of SSBs, enhanced awareness of their health effects, or some other reasons.

In addition, we collected information on the price of nine of the most popular beverages in different formats (large and small; with and without sugar; soft, fruit, and energy drinks; registered and own-brand beverages), sold in the seven main supermarkets present both in Madrid and in Barcelona, covering more than $75 \%$ of the beverages market share [36]. As beverage prices in supermarkets are the same on-site than online, but do vary depending on your place of residence, data prices were collected online by including the postal code (Madrid vs. Barcelona) in the supermarket web pages, in the months of March 2017 and March 2018.

\section{Statistical analysis}

We conducted a descriptive study of the sociodemographic data collected in each of the surveys (preand post-taxation) for each of the cities (Barcelona and Madrid) and calculated the corresponding prevalences of regular consumption of each type of beverage. Similarly, we calculated the frequency of attitudes to and opinions expressed about the tax in the survey. Comparison of socio-demographic variables was performed using Pearson's $\mathrm{Chi}^{2}$ test for qualitative variables and Student's $\mathrm{t}$ test for quantitative variables.

The measure of association used to assess the effect of the tax was the ratio of post- to pre-tax prevalences of regular consumption with its $95 \%$ confidence interval, obtained using weigthed Poisson regression with robust variance. To obtain the weights, we first defined the variable Group with four categories, resulting from the combination of city and period (1: Barcelona pre-tax, 2: Barcelona post-tax, 3: Madrid pre-tax, and 4: Madrid post-tax). Then, we fitted a multinomial logistic regression to predict Group as a function of the sociodemographic variables included in the survey (age, sex, nationality, educational level and occupational status), resulting in 4 propensity scores (the probability of being in each of the 4 groups) for each individual. The weigths were then created in such a way that each of the groups was weigthed to be similar to the intervention city in the pre period (Barcelona pre-tax). To do that, for each individual, we divided the probability to being in group 1 by the probability to being in the group he or she actually was [37]. In such way, individuals in other groups received a weigth proportional to their probability of being in group 1 relative to the probability of their being in the group they were actually in. Then, we fitted the weigthed Poisson regression models with the interaction term between period (pre-tax: 2017/post-tax: 2018) and city (Barcelona/Madrid), thereby obtaining the adjusted post- versus pre-tax ratio of prevalences of regular consumption in Barcelona, with the change in the prevalence of consumption in Madrid across the same period taken as reference. As 260 subjects (13.5\%) had missing values in educational level, a new category of this variable was created so as to be able to include them in the multivariate regression analyses. Identical analyses were performed to assess the possible effect of the tax on the percentage of own-brand consumers among regular drinkers of taxed beverages.

The tax's impact on the product's end cost to the consumer was obtained by comparing the differences in prices between Madrid and Barcelona main supermarkets before and after the tax's implementation, by container size. All analyses were performed using the STATA statistical software programme [38].

\section{Results}

Table 1 shows the characteristics of the sample. The mean age of participants was 28.7 years, with this being higher in the post-taxation samples. Almost half of the Madrid post-taxation participants were of foreign nationality, double the figure of the remaining subsamples. The Barcelona post-taxation sample had $22.2 \%$ of participants with no formal or primary education only, versus figures of over $40 \%$ for the rest of subsamples. The percentage of students was higher among the pre-taxation participants in both cities, while the highest and lowest percentages of unemployed were seen among the posttaxation participants of Madrid and Barcelona respectively.

Following the tax's introduction, the adjusted prevalence of regular consumers of taxed beverages decreased by $35.2 \%$ in Barcelona and increased by $6.2 \%$ in Madrid 
Table 1 Socio-demographic characteristics of the pre-tax (2017) and post-tax samples (2018) in low-income neighbourhoods of Barcelona (intervention) and Madrid (control)

\begin{tabular}{|c|c|c|c|c|c|c|}
\hline \multirow[t]{3}{*}{$\mathrm{N}$} & \multicolumn{2}{|l|}{ Pre-tax } & \multirow{3}{*}{$\begin{array}{l}p- \\
\text { value } \\
a\end{array}$} & \multicolumn{2}{|l|}{ Post-tax } & \multirow{3}{*}{$\begin{array}{l}p- \\
\text { value a }\end{array}$} \\
\hline & Barcelona & Madrid & & Barcelona & Madrid & \\
\hline & 536 & 450 & & 488 & 455 & \\
\hline \multicolumn{7}{|l|}{ Age, years } \\
\hline Mean (SD) & $27.9(7.8)$ & $26.7(7.9)$ & 0.015 & $29.8(7.2)$ & $30.5(7.2)$ & 0.109 \\
\hline Women, \% & 52.2 & 47.2 & 0.121 & 41.0 & 58.5 & $<0.001$ \\
\hline Nationality, \% & & & 0.535 & & & $<0.001$ \\
\hline Spanish & 77.2 & 78.8 & & 81.6 & 52.1 & \\
\hline Other & 22.8 & 21.2 & & 18.4 & 47.9 & \\
\hline Educational level, \% & $(n=278)$ & $(n=449)$ & 0.086 & $(n=488)$ & $(n=454)$ & $<0.001$ \\
\hline Less than primary & 5.4 & 10.9 & & 3.1 & 6.6 & \\
\hline Primary & 38.5 & 37.2 & & 19.1 & 45.8 & \\
\hline Secondary & 38.9 & 36.1 & & 45.3 & 37.4 & \\
\hline University & 17.3 & 15.8 & & 32.6 & 10.1 & \\
\hline Occupational status, \% & $(n=531)$ & $(n=449)$ & 0.009 & $(n=486)$ & & $<0.001$ \\
\hline Gainfully employed & 39.9 & 50.6 & & 68.1 & 59.3 & \\
\hline Unemployed & 16.4 & 14.7 & & 10.3 & 20.2 & \\
\hline Housework & 5.8 & 4.9 & & 3.1 & 5.9 & \\
\hline Student & 37.8 & 29.8 & & 18.5 & 14.5 & \\
\hline
\end{tabular}

${ }^{a}$ Student's $\mathrm{t}$ test for age and Pearson's $\mathrm{Chi}^{2}$ test for the remaining variables

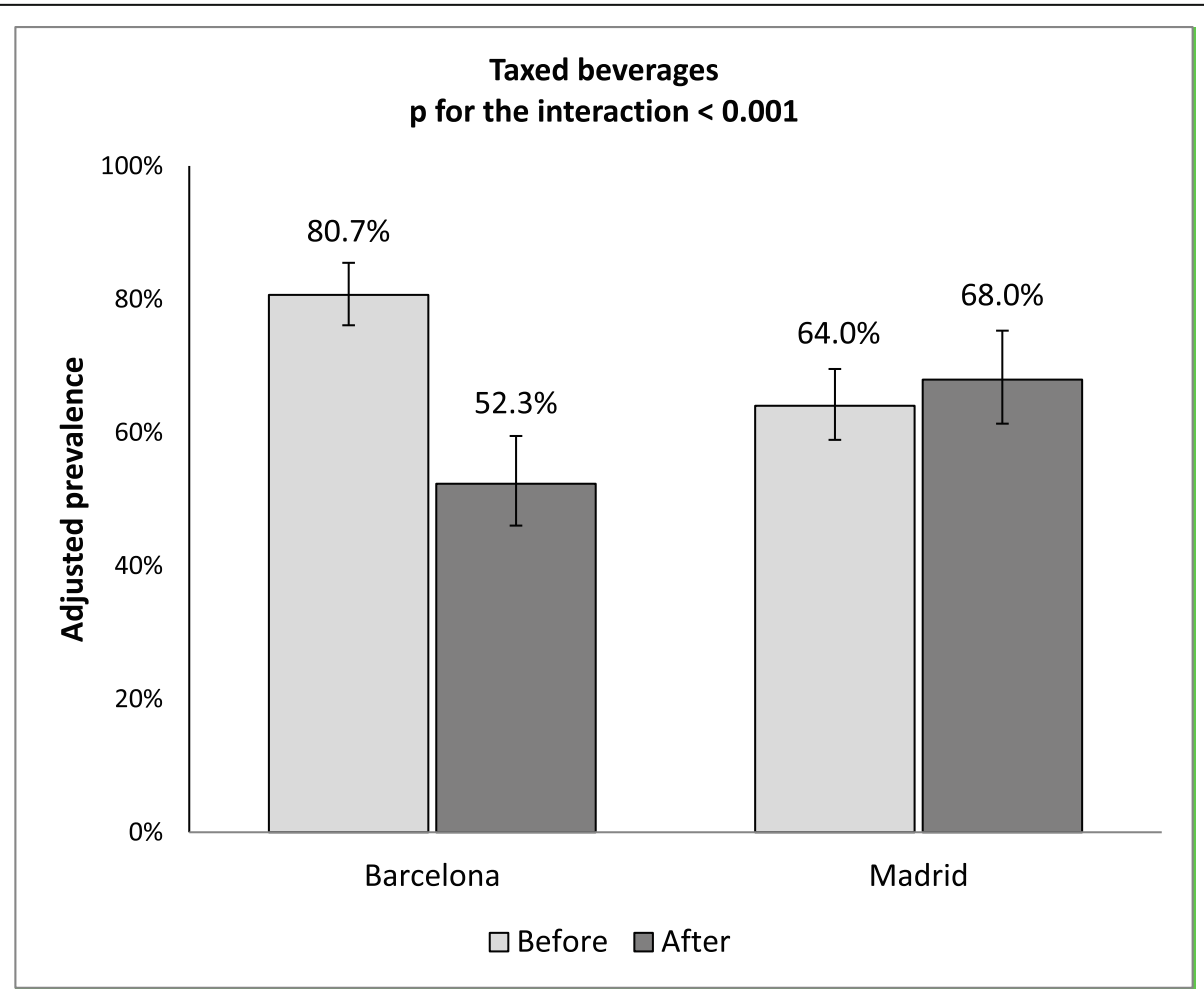

Note: Prevalences were obtained using Poisson regression models with robust variance weighted using propensity scores.

Fig. 2 Adjusted prevalences of consumption of taxed beverages before (2017) and after (2018) taxation in Barcelona (intervention) and Madrid (control) 
(Fig. 2). Table 2 shows the pre- and post-tax prevalence of regular consumers in both cities and the adjusted effect of the tax in Barcelona for each type of beverage, taking the change observed in Madrid over the same period as reference. Pre-tax prevalence was higher in Barcelona than Madrid both for taxed and untaxed beverages $(76.9 \%$ vs. 63.8 and $80.8 \%$ and $68.2 \%$, respectively), whit the highest prevalences being for soft drinks $(50 \%$ vs. $47.1 \%)$. Whereas the post-tax prevalence of consumers of all three types of taxed beverages decreased in Barcelona, it increased in Madrid, with the single exception of energy drinks which showed no variation. Taking Madrid as reference, the prevalence of regular consumers of taxed beverages in Barcelona fell by $39 \%(p<0.01)$, with a $29 \%$ fall in the prevalence of consumers of soft drinks, an $70 \%$ fall in that of fruit drinks and $77 \%$ fall in that of energy drinks $(p<0.01)$. The percentage of consumers of sports drinks and sugar-sweetened milk drinks decreased in both cities post-tax, though the fall was sharper in Barcelona, resulting in a reduction in the prevalence of such consumers with respect to Madrid of 58 and $66 \%$ respectively $(p<0.01)$.
After the tax, the prevalence of consumers of untaxed beverages increased by $7.4 \%$ in Madrid and $4 \%$ in Barcelona (Fig. 3), though neither of these differences proved statistically significant, which translated as a lack of effect when it came to comparing the change in prevalence between the two cities (Table 2). Similarly, among regular drinkers of taxed beverages, the percentage of own-brand consumers remained stable in Barcelona as compared to Madrid.

A total of $83.4 \%$ of the post-taxation participants in Barcelona knew of the existence of the tax on SSBs, and $37.4 \%$ of these reported having changed their consumption habits of non-alcoholic beverages as a consequence (Table 3): $77 \%$ of those who changed their habits reported having reduced their consumption, $13.8 \%$ reported having partly or totally replaced the taxed beverages with other untaxed or own-brand drinks, and the remainder reported having combined reduction in consumption with some degree of substitution. The main reason given for changing consumption patterns was the increase in price in $75 \%$ of the sample, with this being the exclusive reason in $67.1 \%$; similarly, while $30.3 \%$ reported that the change was due to enhanced

Table 2 Prevalence of regular consumption of taxed and untaxed beverages in low-income neighbourhoods of Barcelona and Madrid before (2017) and after (2018) taxation, and ratio of post- to pre-tax prevalence in Barcelona with respect to Madrid

\begin{tabular}{|c|c|c|c|c|c|c|}
\hline \multicolumn{3}{|c|}{ Barcelona $(n=1024)$} & \multicolumn{3}{|c|}{ Madrid $(n=905)$} & \multirow{2}{*}{$\begin{array}{l}\text { Ratio of post- } \\
\text { to pre-tax } \\
\text { prevalence in } \\
\text { Barcelona } \\
\text { relative to } \\
\text { Madrid } \\
(95 \% \mathrm{Cl})^{\mathrm{a}}\end{array}$} \\
\hline $\begin{array}{l}\text { Pre-tax } \\
\%(95 \% \mathrm{Cl})\end{array}$ & $\begin{array}{l}\text { Post-tax } \\
\%(95 \% \text { Cl) }\end{array}$ & $\begin{array}{l}\text { Post- to pre-tax } \\
\text { difference (\%) }\end{array}$ & $\begin{array}{l}\text { Pre-tax } \\
\%(95 \% \mathrm{Cl})\end{array}$ & $\begin{array}{l}\text { Post-tax } \\
\%(95 \% \mathrm{Cl})\end{array}$ & $\begin{array}{l}\text { Post- to pre-tax } \\
\text { difference }(\%)\end{array}$ & \\
\hline
\end{tabular}

\begin{tabular}{|c|c|c|c|c|c|c|c|}
\hline \multicolumn{8}{|l|}{ Taxed beverages } \\
\hline Soft drinks & $\begin{array}{l}50.0 \\
(45.8-54.2)\end{array}$ & $\begin{array}{l}46.3 \\
(41.9-50.8)\end{array}$ & $-3.7(-7.4)$ & $\begin{array}{l}47.1 \\
(42.5-51.7)\end{array}$ & $\begin{array}{l}54.3 \\
(49.7-58.9)\end{array}$ & $7.2(15.2)$ & $\begin{array}{l}0.71 \\
(0.54-0.93)\end{array}$ \\
\hline Fruit drinks & $\begin{array}{l}42.9 \\
(38.7-47.1)\end{array}$ & $11.3(8.5-14.1)$ & $-31.6(-73.7)$ & $\begin{array}{l}20.2 \\
(16.5-23.9)\end{array}$ & $\begin{array}{l}27.0 \\
(22.9-31.1)\end{array}$ & $6.8(33.7)$ & $\begin{array}{l}0.30 \\
(0.19-0.49)\end{array}$ \\
\hline Energy drinks & $\begin{array}{l}36.8 \\
(32.7-40.8)\end{array}$ & $\begin{array}{l}14.3 \\
(11.2-17.5)\end{array}$ & $-22.4(-61.0)$ & $\begin{array}{l}22.2 \\
(18.4-26.1)\end{array}$ & $\begin{array}{l}22.6 \\
(18.8-26.5)\end{array}$ & $0.4(1.9)$ & $\begin{array}{l}0.23 \\
(0.14-0.38)\end{array}$ \\
\hline Total & $\begin{array}{l}76.9 \\
(73.3-80.4)\end{array}$ & $\begin{array}{l}52.0 \\
(47.6-56.5)\end{array}$ & $-24.8(-32.3)$ & $\begin{array}{l}63.8 \\
(59.3-68.2)\end{array}$ & $\begin{array}{l}69.0 \\
(64.7-73.3)\end{array}$ & $5.2(8.2)$ & $\begin{array}{l}0.61 \\
(0.50-0.74)\end{array}$ \\
\hline \multicolumn{8}{|l|}{ Other taxed beverages ${ }^{\mathrm{b}}$} \\
\hline Sports drinks & $\begin{array}{l}26.9 \\
(23.1-30.6)\end{array}$ & $9.2(6.6-11.8)$ & $-17.6(-65.7)$ & $\begin{array}{l}15.8 \\
(12.4-19.2)\end{array}$ & $11.9(8.9-14.9)$ & $-3.9(-24.8)$ & $\begin{array}{l}0.42 \\
(0.22-0.81)\end{array}$ \\
\hline Sugar-sweetened milk drinks & $\begin{array}{l}30.0 \\
(26.1-33.9)\end{array}$ & $5.9(3.8-8.0)$ & $-24.1(-80.2)$ & $\begin{array}{l}28.9 \\
(24.7-33.1)\end{array}$ & $\begin{array}{l}20.2 \\
(16.5-23.9)\end{array}$ & $-8.7(-30)$ & $\begin{array}{l}0.34 \\
(0.19-0.64)\end{array}$ \\
\hline Untaxed beverages $^{c}$ & $\begin{array}{l}80.8 \\
(77.4-84.1)\end{array}$ & $\begin{array}{l}83.6 \\
(80.3-86.9)\end{array}$ & $2.8(3.5)$ & $\begin{array}{l}68.2 \\
(63.9-72.5)\end{array}$ & $\begin{array}{l}76.5 \\
(72.6-80.4)\end{array}$ & $8.3(12.1)$ & $\begin{array}{l}1.03 \\
(0.90-1.20)\end{array}$ \\
\hline Taxed own-brand beverages ${ }^{d}$ & $\begin{array}{l}43.4 \\
(38.6-48.3)\end{array}$ & $35(29.1-40.9)$ & $-8.4(-19.4)$ & $\begin{array}{l}37.3 \\
(31.7-42.9)\end{array}$ & $\begin{array}{l}50.0 \\
(44.4-55.6)\end{array}$ & $12.7(34.1)$ & $\begin{array}{l}0.89 \\
(0.62-1.26)\end{array}$ \\
\hline
\end{tabular}

${ }^{a}$ The ratio of prevalences was obtained from the interaction between year (pre-tax: 2017/post-tax: 2018) and city (Barcelona/Madrid) in Poisson regression models with robust variance adjusted for age, sex, educational level, nationality and occupational status

${ }^{b}$ Energy drinks and sugar-sweetened milk drinks are shown in a separate category, due to the inclusion of certain varieties not subject to the tax by reason of their lower sugar content

' Includes: fruit drinks, soft drinks, flavoured water, vegetable drinks and juices, and drinking yoghurts

d Prevalence of use of own-brand products among consumers of taxed beverages 


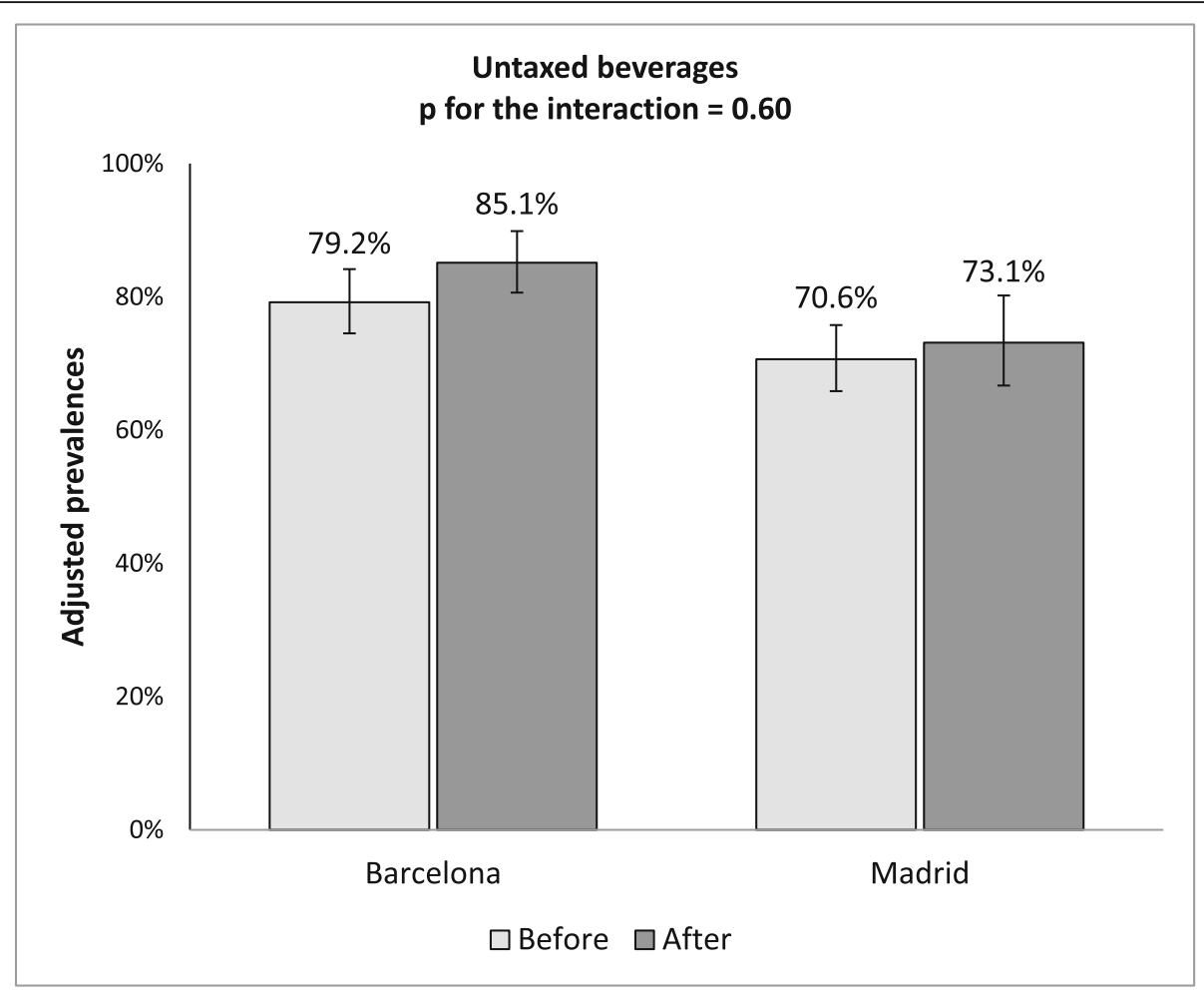

Note: Prevalences were obtained using Poisson regression models with robust variance weighted using propensity scores.

Fig. 3 Adjusted prevalences of consumption of untaxed beverages before (2017) and after (2018) taxation in Barcelona (intervention) and Madrid (control)

Table 3 Knowledge of the tax on sugar-sweetened beverages, changes in consumption, and reasons for the change reported by the 455 participants in the post-tax sample (2018) in lowincome neighbourhoods of Barcelona

\begin{tabular}{ll}
\hline & N (\%) \\
\hline Knows of the existence of the tax $^{\text {Reports change in consumption }}{ }^{\mathrm{a}}$ & $407(83.4 \%)$ \\
${\text { Direction of change in consumption }{ }^{\mathrm{b}}}^{\text {Reduction in consumption }}$ & $152(37.3 \%)$ \\
Replacement by untaxed beverages $_{\text {Replacement by own-brand beverages }}$ & $117(77.0 \%)$ \\
A combination of the above & $9(5.9 \%)$ \\
Reason for change in consumption ${ }^{\text {b }}$ & $12(7.9 \%)$ \\
Increase in price & $14(9.2 \%)$ \\
Health awareness & $102(67.1 \%)$ \\
Increase in price and health awareness & $34(22.4 \%)$ \\
Others & $12(7.9 \%)$
\end{tabular}

${ }^{a}$ Percentage calculated with respect to the 407 participants who knew of the existence of the tax

b Percentage of the 152 participants who reported having changed their consumption of beverages as a result of the tax's introduction awareness of the health effects of SSBs, this was cited as the exclusive reason by $22.4 \%$.

As compared to Madrid, mean prices rose by $8.3 \%$ for drinks in small-sized containers (less than $1 \mathrm{l}$ ) and $17.5 \%$ for the rest. The greatest price rises were observed for own-brand soft drinks in large-sized containers, with an increase of $26.3 \%$.

\section{Discussion}

This is the first study to assess the impact of the Catalonian excise tax on consumption of SSBs by young residents of low-income neighbourhoods in Spain. While the prevalence of regular consumers of taxed beverages fell by $39 \%$ in Barcelona as compared to Madrid, no change was observed in the prevalence of consumers of untaxed beverages. Among regular drinkers of taxed beverages, the percentage of own-brand consumers remained unchanged in Barcelona as against Madrid. After the tax's introduction, the main reason cited by just over two-thirds of those surveyed in the Barcelona sample for reducing their consumption of SSBs was the rise in price, followed by a heightened awareness of their health effects. 
This paper provides the first evidence of the effect on SSB consumption for a tiered SSB tax design designed through legislation to be fully passed through to consumers. In our study, more than two thirds of those who reported a reduction in SSB consumption stated the increase in price as a reason for change, like in Hungary [39]. Hence, being affordability a major driver of SSB purchasing behaviours [40], while targeting manufacturers may increase public support for the tax, like in the UK [23], its potential effect on SSB consumption can be comprised if the tax is not fully passed to consumers. Our data on SSB prices show that the tax was passed through to consumers, with $8.3 \%$ for small-sized containers and $17.5 \%$ for large-sized containers, using the change in prices in Madrid over the same period as reference for comparison purposes. The greatest price rise, $26.3 \%$, was for taxed own-brand beverages in large-sized containers, as expected being the tax charged at a fixed amount per volume of liquid. Health awareness was the second reason for change, by almost one third of those who reported a reduction in SSB consumption, corroborating a signalling effect suggested in previous studies $[31,39]$. The fact that the tax was justified by health reasons and implemented after a long public debate in the mass media [41], has probably contributed to the high levels of public awareness of both the tax and the health risks of SSBs.

In accordance with the results of previous reviews [30, 42 ], price elasticity for SSBs is around -1.00 , though this magnitude is higher among the young, socioeconomically underprivileged population, such as that of our study. Analysed by type of beverage, elasticity is greater for fruit and sports drinks. In a New Zealand study, elasticity for the two lower quintiles of socioeconomic level was -2 to -3 for soft drinks and -3 to - 5 for energy drinks [43]. Consistent with that, the effect magnitude in our study was higher for fruit drinks, energy drinks and sports drinks, an outcome that was likewise observed in Berkeley [26], using the same methodology, and in Mexico [44], using an SSB-sales time series. The results of the assessment in Mexico show that the magnitude of the effect is negligible in the first months post-taxation and that it then becomes steadily more intense until reaching a peak at 12 months, coinciding with the period during which we carried out our assessment. In contrast, consumption of untaxed beverages increased in Mexico during the first months and then fell to pre-tax levels at 1 year of the tax's introduction, a result consistent with the lack of effect observed by us, at 1 year post-tax, for untaxed beverages.

According to the Spanish Health Survey, the prevalence of soft drink regular consumers in 2016 and 2017 was higher in the population of all ages of Catalonia than in that of Madrid (43\% vs. 35,9\%) [45], like in our study (50\% vs. 47,1\%). As expected, the figures were higher in our study, with a sample of young people from deprived areas. In Hungary, the only European country to have conducted a formal assessment of the tax on SSBs, using a population sample over the age of 18 years, the prevalence of regular consumers of soft drinks at 1 year of the tax's introduction fell by $20 \%$, a figure lower than the $29 \%$ observed in our study, with younger people living in poorer neighbourhoods, though this rose to $25 \%$ in the group with the lowest educational level [39]. This is consistent with larger reductions in taxed bevegares observed in Mexico among high purchasers [46]. Again, the effect in Hungary was of a greater magnitude for energy drinks, but not as much as in Barcelona. This difference may be due in part, to the fact that the impact is greater in the younger population [24], such as that of our study. However, it could also be due to the fact that the percentage of pre-tax consumers was higher in Catalonia (36.8\%) than in Hungary (22\%), which suggests a possible floor effect, something that should be analysed in future studies, since the prevalence of regular consumers at 1 year of the tax's introduction was very similar (14.3 and $16 \%$ respectively).

Two main arguments are levelled against the tax on SSBs [47]. The first is that it is a regressive, discriminatory measure: nonetheless, the higher prevalence of consumption in low-income Spanish families [3] and the intensity of response observed in this study, which targeted neighbourhoods with the lowest income per capita in Madrid and Barcelona, may well translate as future health benefits for the more underprivileged population [48] if, as observed in low-income neighborhoods of Berkley after 3 years of the SSBs tax, the reduction in frequency of consumption persist over time [49]. The fall in frequency of regular consumers of SSBs in the Spanish child and adolescent population during the economic crisis was 2 to 3 times sharper in the low-income stratum, among which the percentage of daily consumers fell by $50 \%$, an impact similar to that detected in our study [3]. The second argument against the tax is that any effect may be offset by increased consumption of similar products, such as own-brand beverages or less healthy products. In Denmark, the tax on fats caused customers of the more expensive supermarkets to shift to discount stores [24]. In our study, although $7.9 \%$ of those who changed their consumption habits in Barcelona reported that they had partially or totally replaced the taxed beverages with own-brand beverages, the percentage of consumers of taxed beverages who opt for own-brand varieties remained unchanged.

\section{Limitations}

Owing to the quasi-experimental design, causal relationships cannot be established with certainty, due to the 
possibility of unmeasured or residual confounding. The method of recruitment and the wheather varying conditions may explain the fairly significant sociodemographic differences between groups. To control for these confounding factors, we used a control group and adjusted the regression models for socio-demographic variables using propensity scores. Our model also relies on the common trends assumption [50]. Using monthly data from the Spanish Food Purchases Panel [36], similar trends were observed and no violation of the common trends assumption was found in soft drink sales for both cola drink taxed $(p=0.97)$ and untaxed $(p=0,87)$ bevegares (Additional files 1 and 2). Prices data should also be taken with caution, as they are not representative of local or regional supermarkets, food and grocery stores, bars and restaurants. Another limitation, which hinders comparisons with other studies, is the fact that we only measured the frequency of consumption and not the amount consumed. Even so, our results are internally consistent and in line with those of studies on price elasticity and the tax's differential impact for each type of beverage in other countries where similar measures have been applied. Although the choice of a sample of young adults from low-income neighbourhoods limits our capacity to extrapolate the results to the general population, in studies using broader-based samples the tax has been observed to affect all socio-economic strata, though the magnitude of the effect is less in the highers strata [48]. The presence of $13.5 \%$ of participants with missing values in the educational level variable had no influence on the results, since the category created to include such subjects in the regression models did not prove predictive of SSB consumption, and the effect estimators were very similar when these subjects were included. Lastly, sports drinks and sugar-sweetened milk drinks include some product with sugar levels below the tax threshold, and these categories were thus analysed separately, though the results show a tax effect in the same direction as that of the remaining taxed beverages.

\section{Conclusions}

At 1 year of its introduction, the Catalonian excise tax on SSBs has brought about an important fall in the prevalence of regular consumers of taxed beverages. Future studies will have to assess whether this change is maintained over time or whether it becomes more marked as has been observed in Mexico, and measure, not only the frequency of consumers, but also the amounts consumed, in order to have a more accurate estimator of the tax's impact. In the interim, our results, along with the remaining scientific evidence on the subject, would justify the extension of the measure to the rest of Spain for public health reasons.

\section{Supplementary information}

Supplementary information accompanies this paper at https://doi.org/10. 1186/s12889-019-7908-5.

Additional file 1. Monthly cola drink purchases per capita in Madrid (A) and Barcelona (B) before the tax from January 2013 to Abril 2017. The figures show the evolution in Spanish Food Purchases Panel sample $(N=$ 12,000) of sugary cola drink (taxed beverage), from January 2013 to Abril 2017 (before the tax), in Barcelona (A) and Madrid (B). We can not reject the common trend null hypothesis, as the t-test for regression time coefficients difference with homogenous variances gives a $p$ value of 0.97 .

Additional file 2. Monthly cola light drink purchases per capita in Madrid (A) and Barcelona (B) before the tax from January 2013 to Abril 2017. The figures show the evolution in Spanish Food Purchases Panel sample $(N=12,000)$ of sugary cola light drink (untaxed beverage), from January 2013 to Abril 2017 (before the tax), in Barcelona (A) and Madrid (B). We can not reject the common trend null hypothesis, as the t-test for regression time coefficients difference with homogenous variances gives a $p$ value of 0.87

\section{Abbreviations}

SSBs: Sugar-sweetened beverages; WHO: World Health Organisation

\section{Acknowledgements}

We would like to thank Francisca Santiago for her support in the management of the data.

\section{Authors' contributions}

MAR conceived the study and wrote the first draft of the manuscript. CF participated in the management, analysis and presentation of the data. LS made the main statistical analysis. BS participated in the in the study desing and data interpretation. JP participated in the analysis and interpretation of the data relative to the evolution of SSBs prices. All authors contributed to the revision and approval of the final manuscript.

\section{Funding}

This study was supported by the Spanish Health Research Fund (Fondo de Investigación Sanitaria - FIS) of the Carlos III Institute of Health (Project ENPY 120/18) and the Spanish Consumers' Organisation (Organización de

Consumidores y Usuarios - OCU). The funders had no role in the design of the study, in collection, analysis, and interpretation of data, or in writing the manuscript.

\section{Availability of data and materials}

The datasets used and analysed during the current study are available from the corresponding author on reasonable request.

\section{Ethics approval and consent to participate}

Ethical approval was obtained from our resident Ethics Research Committee (Carlos III Institute of Health). All procedures performed were in accordance with the ethical standards of the institutional research committee and with the 1964 Helsinki declaration and its later amendments or comparable ethical standards. All participants provided informed consent to participate. For minor participants, aged 12 to 15 years, consent was also provided by their parents or their accompanying adult relatives. The informed consent was verbal, as approved by the ethics committee, because no personal data was collected. To better protect participant confidentiality, neither the name nor the ID number or personal address of the participants was collected.

\section{Consent for publication}

Not applicable.

\section{Competing interests}

The authors declare that they have no competing interests.

\section{Author details}

${ }^{1}$ National School of Public Health, Institute of Health Carlos III, Sinesio Delgado, 8, 28029 Madrid, Spain. ${ }^{2}$ National Center of Epidemiology, Institute of Health Carlos III, Madrid, Spain. ${ }^{3}$ CIBER of Epidemiology and Public Health 
(CIBERESP), Madrid, Spain. ${ }^{4}$ Primary Care Health Center Isabel II, Madrid, Parla, Spain.

Received: 4 February 2019 Accepted: 7 November 2019

Published online: 21 November 2019

\section{References}

1. Salcedo V, Gutiérrez-Fisac JL, Guallar-Castillón P, Rodríguez-Artalejo F. Trends in overweight and misperceived overweight in Spain from 1987 to 2007. Int J Obes. 2010;34:1759-65.

2. Gutiérrez-Fisac JL, Guallar-Castillón P, León Muñoz L, Graciani A, Banegas JR, Rodríguez-Artalejo F. Prevalence of Obesity Prevalence of general and abdominal obesity in the adult population of Spain , 2008-2010 : the ENRICA study. Obes Rev. 2012;13:388-92.

3. Ramiro-González M, Sanz-Barbero B, Royo-Bordonada M. Childhood Excess Weight in Spain From 2006 to 2012 . Determinants and Parental Misperception. Rev Esp Cardiol. 2017;70:656-63.

4. Forouzanfar MH, Alexander L, Anderson H, Bachman V, Biryukov S, Brauer M. Global, regional, and national comparative risk assessment of 79 behavioural, environmental and occupational, and metabolic risks or clusters of risks, 1990-2015: a systematic analysis for the global burden of disease study 2015. Lancet. 2015;386:2287-323.

5. Valdés Pizarro J, Royo-Bordonada MA. Prevalence of childhood obesity in Spain: National Health Survey 2006-2007. Nutr Hosp. 2012;27:154-60

6. Malik VS, Pan A, Willett WC, Hu FB. Sugar-sweetened beverages and weight gain in children and adults: a systematic review and meta-analysis. Am J Clin Nutr. 2013;98:1084-102.

7. Balcells E, Delgado-Noguera M, Pardo-lozano R, Mun J, Renom A, Gonza G, et al. Soft drinks consumption, diet quality and BMI in a Mediterranean population. Public Health Nutr. 2011;14:778-84.

8. Malik VS, Hu FB. Fructose and Cardiometabolic health. J Am Coll Cardiol. 2015;66:1615-24.

9. Imamura F, Connor LO, Ye Z, Mursu J, Hayashino Y, Bhupathiraju SN, et al. Consumption of sugar sweetened beverages, artificially sweetened beverages, and fruit juice and incidence of type 2 diabetes: systematic review, meta-analysis, and estimation of population attributable fraction. BMJ. 2015:351:h3576.

10. Keller A, Heitmann BL, Olsen N. Review article sugar-sweetened beverages, vascular risk factors and events: a systematic literature review. Public Health Nutr. 2015;18:1145-54

11. Koning LD, Malik VS, Kellogg MD, Rimm EB, Willett WC, Hu FB. Sweetened beverage consumption, incident coronary heart disease, and biomarkers of risk in men. Circulation. 2012;125:1735-41.

12. Encuesta Europea de Salud en España 2014. Instituto Nacional de Estadistica, Madrid 2014 https://www.mscbs.gob.es/estadEstudios/ estadisticas/EncuestaEuropea/Enc_Eur_Salud_en_Esp_2014_datos.htm. Accessed 27 Sep 2019.

13. Singh GM, Micha R, Khatibzadeh S, Lim S, Ezzati M, Mozaffarian D. Estimated global, regional, and National Disease Burdens Related to sugar-sweetened beverage consumption in 2010. Circulation. 2015;132:639-66.

14. Guelinckx I, Iglesia I, Bottin JH, De Miguel-Etayo P, González-Gil EM, SalasSalvadó J, et al. Intake of water and beverages of children and adolescents in 13 countries. Eur J Nutr. 2015;54:69-79.

15. Ruiz E, Ávila JM, Valero T, Pozo S, Rodriguez P, Aranceta-Bartrina J, et al. Macronutrient distribution and dietary sources in the Spanish population: findings from the ANIBES study. Nutrients. 2016;8:177.

16. Encuesta Nacional de Salud de España 2011/2012. Ministerio de Sanidad, Consumo y Bienestar Social, Madrid 2012. https://www.mscbs.gob.es/ estadEstudios/estadisticas/encuestaNacional/encuesta2011.htm.

17. Vienna Declaration on Nutrition and Noncommunicable Diseases in the Context of Health 2020. WHO regional Office for Europe, Copenhagen 2013. http:/www.euro.who.int/_data/assets/pdf_file/0005/193253/CONSENSUSVienna-Declaration-5-July-2013.pdf. Accessed 27 Sep 2019.

18. European Food and Nutrition Action Plan 2015-2020. WHO regional Office for Europe, Copenhagen 2014. http://www.euro.who.int/_data/assets/pdf_ file/0008/253727/64wd14e_FoodNutAP_140426.pdf. Accessed 27 Sep 2019.

19. Report of the Commission on Ending Childhood Obesity. World Health Organization, Geneva. 2016. https://www.who.int/end-childhood-obesity/ publications/echo-report/en/. Accessed 27 Sep 2019.

20. Backholer K, Blake M, Vandevijvere S. Sugar-sweetened beverage taxation: an update on the year that was 2017. Public Health Nutr. 2017;20:3219-24.
21. Ortún V, López-Valcárcel B, Pinilla J. El impuesto sobre bebidas azucaradas en España. Rev Esp Salud Pública. 2016;90:e1-e13.

22. Generalitat de Catalunya. Ley 5/2017, de 28 de marzo, de medidas fiscales, administrativas, financieras y del sector público y de creación y regulación de los impuestos sobre grandes establecimientos comerciales, sobre estancias en establecimientos turísticos, sobre elementos radiotóxicos, sobre bebidas azucaradas envasadas y sobre emisiones de dióxido de carbono. Boletín Oficial del Estado, Barcelona. 2017. https://www.boe.es/eli/es-ct/// 2017/03/28/5. Accessed 27 Sep 2019

23. Pell D, Penney T, Hammond D, Vanderlee L, White M, Adams J. Support for, and perceived effectiveness of, the UK soft drinks industry levy among UK adults: cross-sectional analysis of the International Food Policy Study. BMJ Open. 2019:9:e026698.

24. Using Price Policies to Promote Healthier Diets. WHO Regional Office for Europe, Copenhagen. 2015. https://apps.who.int/iris/handle/10665/156403. Accessed 27 Sep 2019.

25. Zhong Y, Auchincloss A, Lee B, Kanter G. The short-term impacts of the Philadelphia beverage tax on beverage consumption. Am J Prev Med. 2018; 55:26-34.

26. Falbe J, Thompson HR, Becker CM, Rojas N, Mcculloch CE, Madsen KA. Impact of the Berkeley excise tax on sugar-sweetened beverage consumption. Am J Public Health. 2016;106:1865-71.

27. Colchero MA, Rivera-Dommarco J, Popkin BM, Ng SW. In Mexico, evidence of sustained consumer response two years after implementing a sugarsweetened beverage tax. Health Aff. 2017;36:546-71.

28. Alvarado M, Unwin N, Sharp SJ, Hambleton I, Murphy MM, Samuels TA, et al. Assessing the impact of the Barbados sugar-sweetened beverage tax on beverage sales: an observational study. Int J Behav Nutr Phys Act. 2019;16:13

29. Caro JC, Corvala C, Taillie LS, Reyes M, Silva A, Popkin B. Chile's 2014 sugarsweetened beverage tax and changes in prices and purchases of sugarsweetened beverages: an observational study in an urban environment. PLoS Med. 2018;15:e1002597.

30. Teng AM, Jones AC, Mizdrak A, Signal L, Genç M, Wilson N. Impact of sugarsweetened beverage taxes on purchases and dietary intake: systematic review and meta-analysis. Obes Rev. 2019:20:1187-204.

31. Álvarez-Sánchez C, Contento I, Jiménez-Aguilar A, Koch P, Gray HL, Guerra $L A$, et al. Does the Mexican sugar-sweetened beverage tax have a signaling effect? ENSANUT 2016. PLoS One. 2018;13:e0199337.

32. La Salut a Barcelona 2015. Agència de Salut Pública, Barcelona. 2016. https:/www.aspb.cat/wp-content/uploads/2016/11/Informe-Salut-2015.pdf. Accessed 27 Sep 2019

33. Díaz-Olalla J. Benítez-Robredo T. Estudio de Salud de La Ciudad de Madrid 2014. Ayuntamiento de Madrid:2015 http://www.madridsalud.es/ publicaciones/OtrasPublicaciones/EstudioSaludCiudadMadrid.pdf. Accessed 27 Sep 2019.

34. Fiscal Policies for Diet and the Prevention of Noncommunicable Diseases. World Health Organization. Geneva; 2016. https://www.who. int/dietphysicalactivity/publications/fiscal-policies-diet-prevention/en/. Accessed 27 Sep 2019

35. Nissensohn M, López-Ufano M, Castro-Quezada I, Serra-Majem L. Assessment of beverage intake and hydration status. Nutr Hosp. 2015; 31(Suppl. 3):62-9 http://www.aulamedica.es/nh/pdf/8753.pdf. Accesed 5 Nov 2019.

36. Martín V. Consumo de bebidas refrescantes en España. Distrib y Consum. 2014;3:22-35.

37. Stuart E, Haiden A, Duckworth K, Simmons J, Song Z, Chernew M, et al. Using propensity scores in difference-in-differences models to estimate the effects of a policy change. Health Serv Outcome Res Methodol. 2014;14:166-82

38. StataCorp. Stata Statistical Software: Release 13. College Station, Texas. 2013.

39. Martos E, Bakacs M, Joó T, Kaposvári C, Nagy B, Sarkadi E, et al. Assessment of the impact of a public health product tax WHO regional Office for Europe. Copenhagen: World Health Organization; 2016. http://www.euro. who.int/_data/assets/pdf_file/0008/332882/assessment-impact-PH-taxreport.pdf. Accessed 27 Sep 2019

40. Ferretti F, Mariani M. Sugar-sweetened beverage affordability and the prevalence of overweight and obesity in a cross section of countries. Glob Health. 2019;15:30

41. Royo-Bordonada MÁ. Captura corporativa de la salud pública. Rev Bio y Der. 2019;45:25-41. 
42. Powell LM, Chriqui JF, Khan T, Wada R, Chaloupka FJ. Assessing the potential effectiveness of food and beverage taxes and subsidies for improving public health: a systematic review of prices, demand and body weight outcomes. Obes Rev. 2013;14:110-28.

43. Ni Mhurchu C, Eyles H, Schilling C, Yang Q, Kaye-Blake W, Genç M. Food prices and consumer demand: differences across income levels and ethnic groups. PLoS One. 2013;8:e75934.

44. Colchero MA, Popkin BM, Rivera JA, Ng SW. Beverage purchases from stores in Mexico under the excise tax on sugar sweetened beverages: observational study. BMJ. 2016;352:h6704.

45. Encuesta Nacional de Salud de España 2017. Ministerio de Sanidad, Consumo y Bienestar Social, Madrid 2017. https://www.mscbs.gob.es/ estadEstudios/estadisticas/encuestaNacional/encuesta2017.htm. Accessed 27 Sep 2019

46. Ng SW, Rivera JA, Popkin BM, Colchero MA. Did high sugar-sweetened beverage purchasers respond differently to the excise tax on sugarsweetened beverages in Mexico? Public Health Nutr. 2018:22:750-6.

47. Wright A, Smith KE, Hellowell M. Policy lessons from health taxes: a systematic review of empirical studies. BMC Public Health. 2017;17:583.

48. Sassi F, Belloni A, Mirelman AJ, Suhrcke M, Thomas A, Salti N, et al. Equity impacts of price policies to promote healthy behaviours. Lancet. 2018;391: 2059-70.

49. Lee MM, Falbe J, Schillinger D, Basu S, Mcculloch CE, Kristine A. Sugarsweetened beverage consumption 3 years after the Berkeley, California, sugar-sweetened beverage tax. Am J Public Health. 2019;109:637-9.

50. Wing C, Simon K, Bello-gomez RA. Designing difference in difference studies: best practices for public health policy research. Annu Rev Public Health. 2018;39:453-69.

\section{Publisher's Note}

Springer Nature remains neutral with regard to jurisdictional claims in published maps and institutional affiliations.

Ready to submit your research? Choose BMC and benefit from:

- fast, convenient online submission

- thorough peer review by experienced researchers in your field

- rapid publication on acceptance

- support for research data, including large and complex data types

- gold Open Access which fosters wider collaboration and increased citations

- maximum visibility for your research: over $100 \mathrm{M}$ website views per year

At $\mathrm{BMC}$, research is always in progress.

Learn more biomedcentral.com/submissions 